KULTURA - MEDIA - TEOLOGIA

ISSN 2081-89-71

$2021 \mathrm{nr} 44$, s. 81-84

\title{
Jakub Akonom
}

Akademia Katolicka w Warszawie

\section{Recenzja książki o. Piotra Gruszczyńskiego „Problematyka zła w twórczości J.R.R. Tolkiena. Ocena w świetle teologii katolickiej"}

Piotr Anicet Gruszczyński OFM, Problematyka zła w twórczości J.R.R. Tolkiena. Ocena $w$ świetle teologii katolickiej, Wydawnictwo Katolickiego Uniwersytetu Lubelskiego, Lublin 2018, ss. 321.

$S_{\text {i jednocześnie pełnego symboliki uniwer- }}^{\text {tworzenie wyimaginowanego, barwnego }}$ sum, zawierającego wiele postaci, zachowań i wydarzeń, mogących stanowić metaforyczne nawiązanie do świata rzeczywistego jest

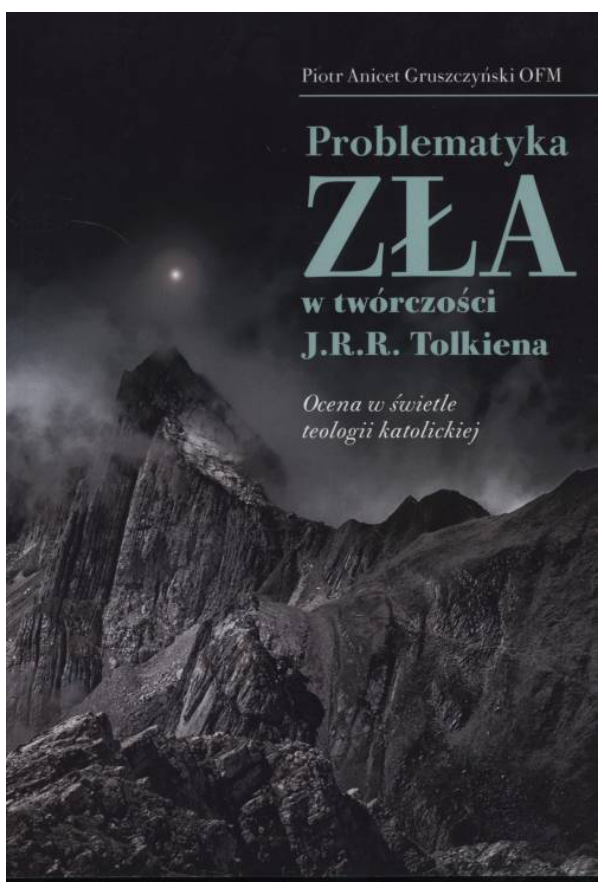
jednym z największych osiągnięć literatury XX wieku, reprezentowanej przez Tolkiena. Historia opisująca odnalezienie i zniszczenie Jedynego Pierścienia wraz z całą mitologią Śródziemia stanowi dobre podłoże do pogłębionych rozważań na temat odwiecznego problemu aktywnego działania zła, które za wszelką cenę próbuje wyprzeć i zastąpić dobro. 0. Gruszczyński podjął się dokonania bardzo odważnej analizy. Należy jednak, już na początku zastrzec, że aby można ją było odpowiednio przestudiować, właściwie interpretując opisywane szczegółowe zagadnienia 
i nawiązania, należy najpierw dokładnie zapoznać się z twórczością J.R.R. Tolkiena. Niniejszy artykuł został przygotowany w taki sposób, aby mogły się z nim zapoznać także osoby, które do tej pory nie miały styczności z twórczością brytyjskiego pisarza.

Recenzowana publikacja ma charakter analityczno-badawczy, i zachowuje wzorową jakość treści, charakteryzuje się wysokim poziomem merytorycznym i dobrym warsztatem technicznym. Monografia pod względem tematyki jest dziełem homogenicznym, skupiającym się na precyzyjnie określonej problematyce. Warto zaznaczyć, iż omawiana książka w dużej mierze dotyczy duchowości oraz fundamentalnych prawd teologicznych, odczytanych $\mathrm{w}$ tolkienowskim obrazie słowa. Przyjęta przez autora metoda badawcza jest właściwa i należy ją uznać za wyczerpującą wobec specyfiki omawianego zagadnienia, skutecznie wykorzystano także obszerny materiał źródłowy.

Dokładna lektura pozwala wniknąć w precyzyjnie nakreślone wątki badawcze, które zostały dokładnie omówione i wyjaśnione przez autor, umożliwiając ich percepcję przez czytelnika. Układ pracy charakteryzuje się dobrym rozmieszczeniem treści zapewniającym właściwą przejrzystość i strukturę tematyczną książki. Monografię otwiera bardzo obszerny, jak na współczesne standardy, odautorski wstęp, wprowadzający w problematykę i zakres pracy (s. 7-31). Główną część konstrukcji całej publikacji stanowią cztery tematycznie podzielone rozdziały, kolejno podzielone na mniejsze podrozdziały oraz zawarte w nich punkty oznaczone literami (s. 33-289). Książkę wieńczy właściwe pod względem długości zakończenie (s. 291-294). Po nim umieszczono wykaz skrótów, ułatwiający czytelnikowi lekturę (s. 295-297). Kolejno ulokowano obszerną bibliografię, zachowującą podział na hierarchię tekstów źródłowych (s. 299-314). W dalszej kolejności znajduje się streszczenie w języku angielskim, umożliwiające zapoznanie się z zarysem problematyki podejmowanej w publikacji także przez osoby zza granicy, dzięki czemu monografia będzie mogła dotrzeć do szerszego kręgu odbiorców (s. 315-316). Całość zamyka spis treści w języku polskim oraz angielskim (s. 317-321).

Rozdział pierwszy dotyka problematyki twórczości mitopoetycznej Tolkiena i stanowi rozbudowaną formę wprowadzenia w problematykę publikacji. Autor ukazuje źródła idei mitopoetyczności, podkreślając pasję lingwistyczną Tolkiena, charakteryzując przy tym istniejące mitologie Północnej Europy. Ojciec Gruszczyński podejmuje także analizę aspektu literatury staro- i średnioangielskiej, 
a przede wszystkim wskazuje na wpływ wydarzeń epoki i kontekstu historycznego na znanego pisarza. W dalszej części rozdziału wskazano wymiar ontologiczny tolkienowskiej twórczości, obszernie bazując na charakterystycznym wierszu Mythopoeia, oraz książce $O$ baśniach. W kontekście ontologicznym dokonano także zestawienia świata wtórnego oraz pierwotnego. W dalszej części podjęto tematykę wymiaru mitologicznego w twórczości Tolkiena, nawiązując do tolkienowskiego rozumienia mitu i jego szczególnej specyfiki. Następnie autor przedstawił obszerną analizę wymiaru teologicznego w twórczości brytyjskiego pisarza. Dokonano zestawienia alegorii względem odniesień, a także przeanalizowano zagadnienie teologii świata wtórnego, zestawiając ją kolejno z teologią świata pierwotnego i nakreślając jej charakter. Na zakończenie rozdziału podjęto bardzo istotną kwestię relacji mitologii i teologii, pozwalającą szerzej spojrzeć na dzieła Tolkiena i zamkniętą w nich spuściznę.

Drugi rozdział publikacji został poświęcony genezie zła. Autor nakreśla wypaczenie zdolności twórczych, opisując m.in. Tolkienowski akt stwórczy, aspekt upadku, zagadnienie dysharmonii w tworzeniu jako istoty upadku, a także kontekst chciwości. W kolejnej części rozdziału przeanalizowano brak akceptacji odniesienia do śmierci, podpierając się cielesno-duchową naturą wybranych bohaterów, jak również przeznaczeniem tolkienowskiej rasy elfów, oraz ludzi. Na tym fundamencie podjęto rozważanie dotyczące bohaterów i istot pochodzących $\mathrm{z}$ uniwersum Tolkiena, mianowicie wskazano na grzech ludzi - pragnienie nieśmiertelności oraz grzech elfów - pragnienie zatrzymania przemijania. W dalszej części rozdziału autor dotyka aspektu deprawacji władzy, podejmując analizę pojęcia „Machiny”, a także odnosząc się do magii i władzy typowo politycznej.

Rozdział trzeci na podstawie dorobku Tolkiena charakteryzuje naturę zła. W pierwszej kolejności autor analizuje problematykę zła moralnego, wychodząc od źródeł moralności oraz ścieżek wiodących ku złu, poprzez aspekt ścieżki ofiary i litości, kończąc ostatecznie na zestawieniu moralności z wartościami. W drugiej części rozdziału ojciec Gruszczyński podejmuje temat zła osobowego, w tym problem istot złych oraz zagadnienie substancjalności zła, a także aspekt zła wcielonego do którego można znaleźć nawiązania w twórczości brytyjskiego twórcy. Trzecia część rozdziału została poświęcona problemowi przeznaczenia. Autor dokonał analizy skuteczności działania wolnej woli wobec działania sił nadnaturalnych, powołał się także na związek muzyki pewnych tolkienowskich postaci wobec przeznaczenia. Następnie podjęto zagadnienie roli przypadku oraz 
interesującą kwestię wolnej woli w zestawieniu z działaniem opatrzności. Owe dwa przywołana w poprzednim zdaniu wątki znacznie poszerzyły obszar badań oraz ubogaciły całą monografię, otwierając ją dodatkowo na niewątpliwe zainteresowanie czytelników.

W ostatnim rozdziale podjęto tematykę przeciwdziałania złu. W pierwszej części tego fragmentu książki autor ukazuje problematykę czynnej walki ze złem opierając się na właściwej walce ze złem wcielonym, logice wojen w świecie tolkienowskich postaci, niewystarczalności wojny oraz dążeniu do sprawiedliwości. Kolejno ojciec Gruszczyński wskazuje na „bierną” walkę ze złem, ukazaną zwłaszcza w historii opisującej wojnę o Jedyny Pierścień (źródło władzy, zdolne skusić do zła), a także podejmuje zagadnienie dyskatastrofy oraz eukatastrofy charakteryzując jej obecność na kartach dzieł brytyjskiego pisarza. Trzecia część rozdziału czwartego dotyka zła w perspektywie eschatologicznej. Autor wskazuje na eschatologiczny charakter jednej z mitologicznych krain, dotyka także kontekstu eschatologicznej nadziei oraz apokatastazy.

Podejmując próbę konkluzji nad recenzowaną monografią, należy zaznaczyć, iż stanowi ona niejako pomost pomiędzy teologią a filologią, tym samym w znacznym stopniu wyróżnia się od większości prac teologicznych, zachowując oryginalność spojrzenia. Publikacja stanowiąca fundament konsolidacji i przeniknięcia obu dziedzin może uchodzić za przykład poszukiwania nurtów teologicznych nie tylko w samej religii, ale także w pozornie odległych od niej obszarach. Tym samym autor umożliwił czytelnikowi głębsze spojrzenie na teologię jako naukę, stereotypowo tylko zaszufladkowaną jako skostniała i zamknięta w wąskiej specyfice, a realnie pozostająca żywą i otwartą, poszukująca nowych, wypływających z Tradycji nurtów rozwoju i wyjścia ku człowiekowi, przybliżając go jednocześnie do Boga. Nie pozostaje więc nic innego, jako polecić Czytelnikom lekturę omawianej pozycji, która pozwalając zaczerpnąć z bogactwa dzieł J.R.R. Tolkiena skieruje myśl ku zagadnieniom duchowym i pozwoli podjąć refleksję nad realnym działaniem zła.

\section{Biogram}

Jakub Akonom, student Akademii Katolickiej w Warszawie.

ORCID: https://orcid.org/0000-0002-3959-9183 